\title{
"BLANK STOCK" TECHNIQUES IN NORTH CAROLINA
}

\author{
GRADY B. STOTT*
}

The corporation laws of most states provide that the number (or amount) of shares and the characteristics of the shares are to be set forth in the certificate of incorporation. Consequently, if the corporation seeks to issue stock differing in any detail from the provisions in the certificate there must be a charter amendment. To avoid the delay, trouble and expense of stockholders meetings and the requisite filings, the statutes of a number of states authorize the insertion in the certificate of incorporation of a grant of authority to the directors to determine, by directors' resolution, the characteristics of the shares to be issued. ${ }^{1}$

Accordingly, one may find in the certificate of incorporation in those states a bare statement of the total amount (or number) of shares which the corporation is authorized to issue, or perhaps a general statement classifying the shares into classes (e.g., common and preferred), but with no specifications of details of the various characteristics of differing classes or series of shares; instead a charter clause is found authorizing the directors to fix the characteristics of any issue of shares. Hence the term "blank stock"."

While North Carolina statutes do not authorize "blank stock", in the sense of giving the directors power to fill in the details left unstated in the charter provisions that constitute the basic authorization for the shares in question, a statute has provided since 1903:

"Every corporation has power to create two or more kinds of stock of such classes, with such designations, preferences, and voting powers or re-

* 2nd Year Law Student, Duke University; A.B. Duke University 1947.

1 Dex. Rev. Code c. 65, § 13 (1935); MINN. BUS. CoRp. Act, § 301.14 (1945); CALIF. CoBp. C.A. \& 304 (1947); MD. AN. CoDE § 42 (1939).

2 This term seems to have been first used in Berle, Investors and the Revised Delaware Corporation Act, 29 CoL. L. REv. 563 (1929). 
strictions or qualifications thereof as are prescribed by those holding a majority of its outstanding capital stock entitled to vote."3

One question suggested is whether under the statute the shareholders may by resolution authorize an issue of shares either in excess of the charter limit or differing from such characteristics as may have been stated in the charter. The answer seems clearly: No. The statutory provision prescribing the contents of the certificate of incorporation requires that the amount of the total authorized capital stock, number of shares into which it is divided, par value of each share (if the shares have par value), ${ }^{4}$ and, if more than one class, a description of the different classes, be set forth in the certificate of incorporation. ${ }^{5}$ Moreover, the number (and amount) of the total authorized shares of capital stock stated in the charter determines the amount of organization tax paid to the state. ${ }^{6}$ To permit stockholders to create shares in excess of charter limits would deprive the state of statutory fees. If the charter limit is to be exceeded, then an amendment under the statute is called for. ${ }^{7}$ As for creation of shares inconsistent with the charter, this would seem to be precluded by the very concept of the charter being the basic framework for a corporation. For example, if the charter provides only for par shares, it

3 N.C. Gen. Stat. § 55-61 (1943). The statute originally required a vote of those holding two-thirds of the capital stock outstanding. See amendment, Sec. 2, Chapter 118, Public Laws of N.C. (1925). Twothirds vote is still required if new shares are to have priority in divi. dends or distribution over existing preferred.

Perhaps out of excess caution, draftsmen of charters of North Caro. lina corporations sometimes insert in the charter, as part of the clauses relating to the capital stock, a provision to the effect that the shares may be issued with such designations, preferences, and voting powers or restrictions thereof as are prescribed by those holding a majority of its outstanding capital stock entitled to vote. Such a charter clause, however, would not seem necessary to enable the stockholders to exercise the "blank stock" authorization of the statute.

- If the shares are to be without par value the total number author. ized must be stated in the certificate of incorporation. N.C. GEN. STAT. $\S 55.75$ (1943).

- N.C. GeN. StaT. § 55-2 (1943).

- N.C. GEN. STAT. \& 55-158 (1) (2) (4) (1943).

7 N.C. Gen. StaT. \$55-61 (1943). 
would be awkward, to say the least, for the stockholders to create no-par shares.

The North Carolina statute has certain advantages in facilitating an issue of securities involving registration with the Securities and Exchange Commission. Such registration is almost always a race against time as the audit figures required for registration cannot be more than ninety days old. ${ }^{8}$ Accordingly, the issuer corporation will endeavor to get the issue out within ninety days after the close of the annual audit period. Using figures of that period saves time and expense of an additional audit. It is therefore essential to avoid any delay that would prevent the Registration Statement filed with the SEC from becoming effective within the ninety day period.

However, market conditions may change rapidly, necessitating corresponding changes in dividend rates, redemption figures or other characteristics of an issue of stock, and existing charter provisions fixing the details of an authorized stock not yet issued may be quite inadequate for present market demands. It is highly important to carry out any necessary changes in a proposed new issue as quickly as possible so as to make the appropriate amendment to a Registration Statement with all possible dispatch. Every new amendment to a Registration Statement starts the twenty day waiting period all over again. ${ }^{9}$ Although certain kinds of amendments if filed with the consent of the SEC and with request for acceleration may be treated as being part of the Registration Statement as originally filed; such amendments usually are those which state the offering price or certain underwriting data. Other substantial changes would probably start the period running over again. In a race against time, therefore, any amendment to the

815 U.S.C. \& 77aa(25) (1947).

- 15 U.S.C. \& 77h (1947). By this statute the effective date (meaning, the date on which the security in question can be lawfully offered for sale) is the twentieth day after the filing of the Registration Statement; and if any amendment to the Registration Statement is filed on a later date, the entire Registration Statement is deemed filed as of that date, unless the SEC consents otherwise. 
Registration Statement which would substantially change the characteristics of the security to be offered and which would accordingly start the twenty day waiting period running anew should be filed with as little delay as possible, especially in view of the previously mentioned ninety day period. Even if the change in the details of a security would result in an amendment to the Registration Statement which, because of the SEC's consent to acceleration, would not start a new twenty day waiting period, still the race against time may be so close as to make the North Carolina statute very helpful as will be indicated. Even the mere avoidance of delays incident to preparing, executing and filing a certificate of charter amendment may represent a crucial saving of time and hence an aid to clearing an issue for sale.

The North Carolina statute helps achieve the desired end by dispensing with charter amendments. ${ }^{10}$ Moreover, by the technique of keeping the stockholder's meeting open, and adjourning it to reconvene from time to time, the action of the stockholders can be made to synchronize with the changing details of the new offering. The expense of the stockholders meetings may be kept at a minimum by the same process. When notices are sent out calling for a meeting of the stockholders, the terms can be made sufficiently broad so as to include any business that may arise, especially in regard to creating new securities. In this way any action taken may be handled at the duly called meeting without having to call additional meetings of the stockholders.

North Carolina has not gone the full length of the few states which have "blank stock" provisions in their statutes. As indicated most states with such statutes give authority

\footnotetext{
${ }^{10}$ Of course, a charter amendment in the early stages of preparing for a new issue may be necessary in order to increase the total authorized number or amount of shares of capital stock authorized in the charter. It is not the practice in North Carolina Corporations to carry large amounts of authorized but unissued capital stock for otherwise they would incur additional fees. For the same reason, the amendment to take care of the new issue will probably be only enough to cover those shares.
} 
to fill the "blanks" to the board of directors." It has been said that under statutes of this nature "the position of any stockholder in such a case is, of course, precisely that of a man who has purchased an unknown quantity. He has no certain stake in any given capital set-up. The best that can be done for him is to bring to him the fact that he has assumed the chance of what a board may subsequently do to him."12 The North Carolina statute permits flexibility not present in states where a charter amendment is required to change any detail as to any class of stock, but, unlike other "blank stock" statutes, it preserves corporate democracy. ${ }^{13}$

12 See supra. note 1.

12 Berle, supra. note 2, at 566.

13 One minor criticism, perhaps, might be made of the North Carolina Statute for failing to require any public registry with reference to the details of characteristics of stock created by stockholder's resolution. The effect seems of little significance. Public registry is ordinarily not particularly significant as information; witness the fact; that under the statutes of most states there is no way of telling how much stock a corporation has outstanding simply by looking at the filed papers. 